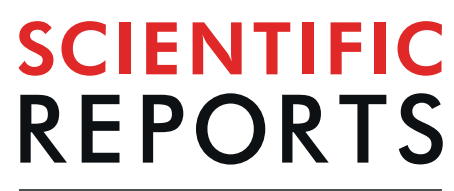

natureresearch

\title{
OPEN Author Correction: Comparison of Four Complete Chloroplast Genomes of Medicinal and Ornamental Meconopsis Species: Genome Organization and Species Discrimination
}

\author{
Xiaoxue Li, Wei Tan, Jiqi Sun, Junhua Du, Chenguang Zheng, Xiaoxuan Tian, Min Zheng, \\ Beibei Xiang \& Yong Wang
}

Correction to: Scientific Reports https://doi.org/10.1038/s41598-019-47008-8, published online 22 July 2019

The Acknowledgements section in this Article is incomplete.

"This work was supported by grants from the Natural Science Foundation of Tianjin (No. 18JCQNJC14000), the Tianjin City High School Science \& Technology Fund Planning Project (No. 20130203), Qinghai Science and Technology Project (No. 2014-HZ-815) and the Ph.D. Candidate Research Innovation Fund of Nankai University. We thank the Guangzhou Gene Denovo Biotechnology Company for assisting with the sequencing analysis."

should read:

"This work was supported by grants from the Natural Science Foundation of Tianjin (No. 18JCQNJC14000), the Tianjin City High School Science \& Technology Fund Planning Project (No. 20130203), the National Natural Science Foundation of China (No. 81303303), Qinghai Science and Technology Project (No. 2014-HZ-815) and the Ph.D. Candidate Research Innovation Fund of Nankai University. We thank the Guangzhou Gene Denovo Biotechnology Company for assisting with the sequencing analysis.”

(c) (i) Open Access This article is licensed under a Creative Commons Attribution 4.0 International License, which permits use, sharing, adaptation, distribution and reproduction in any medium or format, as long as you give appropriate credit to the original author(s) and the source, provide a link to the Creative Commons license, and indicate if changes were made. The images or other third party material in this article are included in the article's Creative Commons license, unless indicated otherwise in a credit line to the material. If material is not included in the article's Creative Commons license and your intended use is not permitted by statutory regulation or exceeds the permitted use, you will need to obtain permission directly from the copyright holder. To view a copy of this license, visit http://creativecommons.org/licenses/by/4.0/.

(C) The Author(s) 2019 